The Economic Journal of Nepal, Vol.41, No. 3 \& 4, July-December 2018 (Issue No. 150) @ Cedecon-TU

\title{
Dynamics of value chain in Climate Resilient Vegetable Practices
}

\author{
Ujjal Raj Acharya ${ }^{1}$
}

\begin{abstract}
The vegetable production is based on the farmer's initiation into which the processes combine with the climate resilient techniques and marketing strategy. The study is also an introduction of an integrated process of climate resilient practices that can help in coping with climate change related problems. The main objective of the study is to analyze the value chain of climate resilient vegetable farming practices. The study was carried out in Udayapur district of Nepal. The data used for the study were from Himalica pilot project initiated by ICIMOD. Primary data were collected from 300 vegetable farmer's households using a semi-structured questionnaire and checklist for interview with farmers groups. The value chain study shows that profit of farmers depends on the market type and farmer's revenue increases when they sell their produce through farmer's co-operatives. The farmers need material support, technology as well as farmers group organization in order to increase the profit and to mitigate the risk from climate change and climate variability. The study found that value chain of vegetable farming has benefits in terms of social, economic and environmental aspects.
\end{abstract}

\section{Background of the Study}

Agriculture is the most important sector of Nepalese Economy and is central to the survival of millions of people. The five year average of agriculture contribution in GDP of Nepal between fiscal year $2011 / 12$ to $15 / 16$ is 3 percent and the major proportion of population live in rural areas with the major source of livelihood based on agriculture sector. However, the decrease in production and productivity in agriculture likely with variability in climate remained a challenge (MOF, 2016).

Nepalese agriculture system is getting affected at different levels of production, consumption and distribution and appears to have pressure in agrarian livelihood due to low capacity to cope with the changes brought on water, temperature and fragile ecosystems by

1 Acharya is a researcher in Practical Action, Nepal. Email: uacharya25@gmail.com 
climate change (Adhikary, 2014; Pant, 2012; Pokhrel \& Pandey, 2011).

Vegetable farming became the additional income source for the household and improved the required dietary necessities of the family members after the implementation of the HIMALICA climate resilient agriculture project. Additionally, farmer's dependency on food stuffs has decreased than before. To ensure sustainable agriculture system, financial and market feasibility of agriculture production is essential. The overall objective of the study is to analyze the value chain in vegetable farming and assess the socio-environmental benefits generated by climate resilient agricultural practices.

\section{Study Area}

The study was conducted in three places namely Bagah, Rautah and Saune of Udayapur district located in Eastern part of Nepal, representing terai, foot hills and mid hill areas, respectively. The district is located between latitude from $26^{\circ} 26^{\prime} 39^{\prime \prime}$ to $27^{\circ} 1^{\prime} 10^{\prime \prime} \mathrm{N}$ and longitude from $86^{\circ} 0^{\prime} 9^{\prime \prime}$ to $87^{\circ} 1^{\prime} 0^{\prime \prime} \mathrm{E}$ with a total land area of 206300 hectare. The district covers total 35068 ha agricultural lands in which Bagah, Rautah and Saune covers 3428 ha, 789ha and 2377 ha as agricultural land with 44.69 percent of irrigation facilities (DADO, 2015/16). The study areas has covered Bagah ward no. 3 and 4, Saune, ward no. 14, which lie in Triyuga municipality and Rautah, ward no.7 lies in Rautamai rural municipality.

The study sites of Udayapur district links three ecological regions with road access: mountain (Solukhumbu), hills (Khotang, Bhojpur and Okhaldhunga) and Terai (Saptari and Sirahah) of the country. In addition to supply vegetables in existing market, the possibility of supplying vegetable stuffs to uphill and downhill shows an abundant market opportunity. So, the People involved in cereals farming (conventional agricultural practices) in limited irrigated land are practicing the vegetable farming in their available land. This has resulted in the employment creation and income generation at local level. The climate resilient agricultural practices project enables the farmers to practice the vegetable farming in the irrigated land as well as in the waste land. So, vegetable farming delivers not only employment as economic benefit but also environmental benefit. Additionally, the vegetable farming increases the social cohesion through co-operation, and sharing of knowledge on farming processes.

\section{Sample Size and Sampling Procedure}

A sample of 300 households, 50 percent of Households from three study sites (Bagah-150, Rauta-90 and Saune- 60) were selected representing the entire twenty five farmers group. The field survey was conducted from August 2017 to February 2018. Firstly, all twenty five farmer's groups were purposively chosen in order to select the sample size. Secondly, household samples were obtained using systematic random sampling with random start from each of the twenty five selected farmer's groups. The household from each farmer's group was selected randomly from the list and then every second household was chosen for the interview. 
60 | The Economic Journal of Nepal (Issue No. 150)

\section{Results and Discussions}

The concept of value chain is the series of activities required to bring a product through various phases of production to its market destination. Farmers are the producers of the vegetable. They sell some portion of their product at home to local traders and some portion to local market directly. Since the local market is small and the production is increasing, the farmers search the option to sell their produce to major market Gaighat. To sell the produce directly to market, basically Gaighat, is not possible for individual farmers due to time consuming process and transportation cost. Therefore, the active participation of farmer's group and co-operatives, collection center for vegetables has been recently established in their places.

\section{Value Chain Analysis of Vegetable Farming}

\section{Stages of Value Chain}

Value Chain is basically divided into three parts:

1. Production stage

2. Collection stage and

3. Trading stage

1. Production Stage: The most important stage is the production stage. Farmers entered into commercial vegetable farming stage and are motivated to finance more on vegetable production to get return from their produce. Vegetable farming is one of the labor intensive activities and 76 percent of cost goes to labor. Farmers produced various types of vegetable on seasonal basis, however, the quantity and types of vegetables varies from season to season.

\section{Figure 1: Distribution of inputs used in Vegetable Farming}



Source: Field Survey, 2017/18 
2. Collection Stage: Farmers were actively involved in production as well as in marketing. Most of the farmers carried their produce and sold to the local market and at home. Due to physical contact and through different means of communication to the market, information on price is not a big issue. In case of Bagah, the farmer's cooperative was beginning to collect the vegetables and charged Rs. 1 per $\mathrm{kg}$ as the service charge. According to institutional survey with farmers' group head, it was found that the market price at home was nearly 2 times less than at the farmer's cooperative. So by establishing farmer's co-operative, they would get the better price. By selling at co-operative, the price of vegetable is increased by 60 percent -100 percent or more than selling to traders at home.

3. Trading Stage: In trading stage of value chain analysis, it was found that the main market for these areas was Gaighat City. The demand of main market (Gaighat) is ever increasing and about 60 percent of the total vegetable is being supplied from India, according to the discussion with local businessman, project officers and farmers cooperatives. So it can be said that, 'there is problem of reaching the market place rather than getting the market price'. In case of Bagah, the main market is about of $5 \mathrm{~km}$ from producers and collection center. The collected vegetables were sold at the market on regular basis. In case of Rauta and Saune, which is quite far from Gaighat market with more than $25 \mathrm{~km}$, hence large quantity were sold in the local market and some quantity were sent to the Gaighat market. The collection center established by the farmers group is in early stage for vegetables collection in all three places in order to reach main market easily.

\section{Farmer's Field to Market Value Chain}

The agriculture service center initiated by farmers group plays a crucial role in value chain. Farmer's sold major portion of their produce to the local market directly (in case of Bagah, local market refers to Gaighat) followed by selling at home. However, some portion was sold in Gaighat market through farmer's co-operatives, which was started recently during study period in order to systematize the value chain especially for future high production. Taking four major vegetable's average price (Cauliflower, Cabbage, Cucumber and Tomato), during survey, the farmers were faced with four selling situations i.e. local traders, local market, Gaighat market, and Collection center/co-operative. It was found that 45 percent of $\mathrm{HHs}$ sold their product to local market. About 32 percent of total respondents sold to the traders at home. Only 19 percent of the households were selling to Gaighat market with the support of farmers group particularly by arranging the vehicle for vegetable transportation. Only 4 percent were selling through collection center run by co-operatives. The collection centers were newly established and survey time was off-season for vegetable production. However, the awareness of farmer on collection centers for increased production in future shows that produce will be channelized through collection center.

Table 1: Major Selling Points of Vegetables

\begin{tabular}{|l|l|}
\hline Selling Place & No of HHs (\%) \\
\hline At home /farm & $97(32.33)$ \\
\hline Local Market & $135(45.00)$ \\
\hline Gaighat & $57(19.00)$ \\
\hline Farmer's Collection center & $11(3.66)$ \\
\hline Total & $\mathbf{3 0 0 ( 1 0 0 )}$ \\
\hline
\end{tabular}

Source: Field Survey, 2017/18 
62 | The Economic Journal of Nepal (Issue No. 150)

\section{Role of Collection Center in Vegetable Value Chain}

Collection centers conducted by farmers saving groups have the critical connection in vegetable value chains. In general, collection centers are owned and managed by the farmers, who organize the production and coordinate the marketing of their produce to get suitable price. So, the tendency to sell vegetable through co-operative is increasing and will increase in future along with increase in production. Every sampled HHs of vegetable farmers involved with a flow of market price information among them through different means of communication. The condition of symmetrical information with the farmers and traders makes the least difference in price variation.

Generally, the price of vegetables is influenced by the large/main market price; in this study, Gaighat is the main market center. In case of traders, they come to the farmer's field and fixed the price after negotiation. In this case, the margin difference ranges about 60 percent to 100 percent of the main market retail price and the average price farmers get was reported to be Rs.25-30. When farmers sell their produce in local market at Rs. 45 on an average, this price is similar to co-operative. When local market is too small for high production, farmer's cooperative arranged vehicle for vegetable transportation, which is one the crucial stage for farmers. This shows that whole sale price of Rs. 50 in Gaighat with the highest price and more than 100 percent profit compared to farmer's field price faced by farmers with local traders. However, this process is complicated and may not incorporate all the farmers.

\section{Flow Chart of Vegetable Price in Different Market}



The less the profit margin at collection centers referred to high profit for farmers. The Gaighat whole sale and retail price differed by 20 percent. According to wholesaler, their profit margin is around 10-20 percent, such that the average retail price faced by consumers 
was accounted to be Rs. 60. Therefore, it can be clearly seen that the profit of farmers increases when they sell their produce to farmer's co-operatives or directly to the market.

\section{Major Value Chain Challenges}

The analysis revealed the following major value chain challenges were faced by farmers during the production level, marketing level and technical processes:

Table 2: Major Challenges in Value Chain of Vegetable Farming

\begin{tabular}{|l|c|}
\hline \multicolumn{1}{|c|}{ Major Challenges } & Number of Household (\%) \\
\hline Lack of irrigation water & $143(47.7)$ \\
\hline Lack of Pests/Diseases management & $79(26.3)$ \\
\hline Poor road access to the market & $52(17.3)$ \\
\hline Unavailability of good quality Seeds & $11(3.6)$ \\
\hline Lack of close technical Support & $15(5)$ \\
\hline Total & $300(100)$ \\
\hline
\end{tabular}

Source: Field Survey, 2017/18

At stages of vegetable production, water availability at farmer's field becomes the major challenge. Altogether 143 respondents, i.e. 47.7 percent of total respondents told that the lack of irrigation water in their field was the major challenge. After that, 26.3 percent revealed pests and diseases as next major challenge. The next challenge was the poor road access to market, which was mentioned by 17.3 percent of the respondents. Other challenges included lack of good quality seeds and technical support in production process reported by 3.6 percent and 5 percent respondents respectively. These factors hinder the production level and this has been creating a major problem in increasing production level.

\section{Coping Strategies for the Shortage Irrigation}

The survey showed the following coping strategies were followed by farmers to overcome water challenges:

Table 3: Coping Strategies to Overcome Water Challenges in Vegetable Farming

\begin{tabular}{|l|c|}
\hline \multicolumn{1}{|c|}{ Strategies to overcome Water shortage challenges } & Number of Household (\%) \\
\hline Using Motor pump & $15(7.77)$ \\
\hline Canal construction & $35(18.13)$ \\
\hline Well construction & $78(40.41)$ \\
\hline Plastic pond & $21(10.88)$ \\
\hline Pipeline distribution & $37(19.17)$ \\
\hline Constructing Water tank at source & $7(3.62)$ \\
\hline Total & $193(100)$ \\
\hline
\end{tabular}

Source: Field Survey, 2017/18 
64 | The Economic Journal of Nepal (Issue No. 150)

Among the respondents, 40.41 percent reported well and tube well construction near to their vegetable field and 7.77 percent felt that electric motor pump would solve their water problem. Most of these respondents were from Bagah, so they had chosen these strategies. Generally they used motor pump for irrigation purpose but the absence of well near to their field was the problem. In case of Rauta and Saune, majority of them told that canal construction, pipeline supply from source, plastic pond construction, and water tank construction at water source would be appropriate strategies to overcome from water challenges.

\section{Strategies to Overcome Marketing Challenges}

The respondents suggested the following strategies to overcome marketing challenges in Value Chain:

Table 4: Strategies to overcome marketing Challenges in Value Chain

\begin{tabular}{|l|c|}
\hline \multicolumn{1}{|c|}{ Strategies to overcome marketing challenges } & Number of Household (\%) \\
\hline Market search for organic vegetables & $63(40.65 \%)$ \\
\hline Vegetable collection center establishment & $67(43.23 \%)$ \\
\hline Motor road and vehicle facility & $25(16.13 \%)$ \\
\hline Total & $155(100 \%)$ \\
\hline
\end{tabular}

Source: Based on calculation

To overcome the marketing challenges, 40.65 percent of the respondents told that search of market for organic vegetable is necessary to get the good price of their produce. Similarly, 43.23 percent viewed that collection center of vegetables in their place is needed to improve value chain. 16.13 percent of the respondents in which majority of them were from Saune noticed that proper road and vehicle management is to be improved to tackle the challenges. Since pests/diseases were the reported as the next challenge and respondents told that technical knowledge to control pest was the strategy to overcome these challenges. Similarly, improved seeds and improved seeds with low price would help to increase their production.

The following activities were recognized by respondents to increase profit in the Value Chain:

Table 5: Activities Needed to Increase Profit in Value Chain

\begin{tabular}{|l|c|}
\hline \multicolumn{1}{|c|}{ Activities } & Number of Household (\%) \\
\hline Increase in off-seasonal vegetable production & $201(67 \%)$ \\
\hline Adopting new techniques & $25(8.33 \%)$ \\
\hline Marketing activities & $74(24.67 \%)$ \\
\hline Total & $300(100 \%)$ \\
\hline
\end{tabular}

Source: Based on calculation 
Majority (67 percent) of the farmer's viewed that off-seasonal vegetables fetched higher price than seasonal one to increase their profit level. Along with seasonal vegetable production 8.33 percent viewed that adopting off-seasonal vegetable farming by using new technology (tunnel construction, drip irrigation, greenhouse and mulching) would increase their profit. Finally, along with these activities and marketing activities (marketing of organic products, establishing co-operatives, and vehicles facilities to access to large markets) would increase the farmer's profit.

\section{Social, Economic and Environmental Benefits of Vegetable Farming}

\section{Employment generation}

Vegetable farming is a labor-intensive process that offers employment in the community particularly for retired persons and women. $227 \mathrm{HHs}$ (76.95 percent) experienced that farmer's leisure time was blatantly cut off after commercial vegetable farming. Before then, most of the HHs spent their leisure time on unproductive activities such as chatting with friends and neighbors, playing cards, wage labor with low productivity. 86.78 percent of the respondents found that their income increased after being involved in the vegetable farming.

\section{Increased saving}

Saving has the positive relationship between Household income obtained from vegetable farming.70 percent of the respondents used to save their income earned from vegetable farming and among them 78 percent of the respondents saved their incomes in the cooperatives.

\section{Production with labor shortage}

Out of total respondents, 74.24 percent didn't use any labor in vegetable farming and relied only on their family member for labor force. However, 25.76 percent respondents used the labor force in average of 14 percent only out of total labor force. The average labor force from family was 2.05 permanently worked in the field. It shows that vegetable farming can be based on own family even with the shortage of labor in labor market.

\section{Increase in intake of nutrition}

Vegetables are the vital source of nutrition for health maintenance and prevention of diseases. A minimum level of daily intake of fruits and vegetables except potatoes and tubers is 400 grams per person i.e. about $150 \mathrm{~kg}$ per person per year (WHO, 2003).During study, it was found that almost all of the respondents told that consumption of vegetable increased nearly by double after the commercial vegetable farming. Hence, increased consumption of vegetables increases the intake of nutrition.

\section{Active women participation}

Women undertake new roles in the society through providing new skills and such skills helps in income generation to add to family income (Sharma, 2017). From gender perspective, women were not only involved in production process but also in decision making in vegetable farming activities. 
66 | The Economic Journal of Nepal (Issue No. 150)

\section{Use of Degraded Lands}

Environmental benefits are experienced by a public through use of waste or degraded land with an increase in greenery through vegetable farming. Before vegetable farming people abandoned portion of their land as grazing area and left it without cultivation due to low production. During survey, it was found that people used fallow land for vegetable production. $58 \mathrm{HHs}$ (53.38 percent) of the total respondents answered that they used fallow land for vegetable farming. The average size of fallow land used per household was of 0.08 hectare (1.58 ropani).

\section{Conc lusion}

The outcome of the study shows that value chain of vegetable farming is based on various factors and has benefits in terms of social, economic and environmental aspects. Among the various factors, this study signifies that increase in profit of farmers depend on the market type, as farmer's revenue increases when they sell their produce in combined form either directly to the market or through farmer's collection center managed by farmer's cooperative. The farmer's need material support, technology and the most important factor is farmers group to increase their profit. These factors over all mitigate the risk from climate change and climate variability. In addition to economic benefits of vegetable farming, there are several positive externalities of environmental and social benefits.

\section{Recommendations}

The production chain of vegetable farming includes production stage and marketing stage, which indicates that farmers require initial support in terms of knowledge regarding formation of farmers groups and cooperative in order to enhance value chain in vegetable farming. Similarly, providing knowledge on climate resilient agriculture practices for offseasonal at local level will encourage the small holder's to commercial farming, which is useful to stabilize the vegetable market. This can be provided under the collaboration of Local Government with project conducted by GOs and NGOs, so that it would ultimately enrich the full-fledged value chain in vegetable farming as well as overall agriculture practices.

\section{References}

Adhikari, J. (2012). Agriculture adaptation practices in South Asia: Case of Nepal. Kathmandu: South Asian Watch on Trade, Economics and Environment (SAWTEE).

DADO (District Agriculture Development Office) (2016). Agricultural Statictical Details and District Profile (2015/16). Udayapur, Gaighat: District Agriculture Development office, Government of Nepal (in nepali version).

Husnain, M. I., \& Khan, M. (2015 July). The public and private benefits from organic farming in Pakistan. SANDEE, Working Paper No. 99-15, 1-25. 
MoF (Ministry of Finance) (2016). Economic Survey 2015/16. Kathmandu: Ministry of Finance, Government of Nepal.

Pant, K. P. (2012, June). Climate change and food security in Nepal. The Journal of Agriculture and Environment, 13, 9-19.

Pokhrel, D. M., \& Pandey, B. (2011). Climate change adaptation: Strategic vision in agriculture. The Journal of Agriculture and Environment, 12,104-112.

Sharma, M. (2017). Women empowerment through value addition in agricultural produce. International Journal of Home Science, 3(1), 163-166.

WHO (World Health Organization). (2003). Diet, Nutrition and the Prevention of Chronic Diseases: Report of a Joint WHO/FAO Expert Consultation. Geneva: World Health Organization. 